\title{
An evaluation of the ability of the Ozone Monitoring Instrument (OMI) to observe boundary layer ozone pollution across China: application to 2005-2017 ozone trends
}

\author{
Lu Shen ${ }^{1}$, Daniel J. Jacob ${ }^{1}$, Xiong Liu ${ }^{2}$, Guanyu Huang ${ }^{3}$, Ke Li ${ }^{1}$, Hong Liao ${ }^{4}$, and Tao Wang ${ }^{5}$ \\ ${ }^{1}$ John A. Paulson School of Engineering and Applied Sciences, Harvard University, Cambridge, Massachusetts 02138, USA \\ ${ }^{2}$ Harvard-Smithsonian Center for Astrophysics, Cambridge, Massachusetts 02138, USA \\ ${ }^{3}$ Environmental \& Health Sciences, Spelman College, Atlanta, Georgia 30314, USA \\ ${ }^{4}$ School of Environmental Science and Engineering, Nanjing University of Information Science \& Technology, \\ Nanjing 210044, China \\ ${ }^{5}$ Department of Civil and Environmental Engineering, The Hong Kong Polytechnic University, Hong Kong
}

Correspondence: Lu Shen (1shen@fas.harvard.edu)

Received: 29 November 2018 - Discussion started: 10 December 2018

Revised: 21 April 2019 - Accepted: 2 May 2019 - Published: 17 May 2019

\begin{abstract}
Nadir-viewing satellite observations of tropospheric ozone in the UV have been shown to have some sensitivity to boundary layer ozone pollution episodes, but so far they have not yet been compared to surface ozone observations collected by large-scale monitoring networks. Here we use 2013-2017 surface ozone data from China's new Ministry of Ecology and Environment (MEE) network of $\sim 1000$ sites, together with vertical profiles from ozonesondes and aircraft, to quantify the ability of tropospheric ozone retrievals from the Ozone Monitoring Instrument (OMI) and to detect boundary layer ozone pollution in China. We focus on summer when ozone pollution in China is most severe and when OMI has the strongest sensitivity. After subtracting the Pacific background, we find that the 2013-2017 mean OMI ozone enhancements over eastern China have strong spatial correlation with the corresponding multiyear means in the surface afternoon observations $(R=0.73)$, and that OMI can estimate these multiyear means in summer afternoon surface ozone with a precision of $8 \mathrm{ppb}$. The OMI data show significantly higher values on observed surface ozone episode days (> $82 \mathrm{ppb}$ ) than on non-episode days. Day-to-day correlations with surface ozone are much weaker due to OMI noise and are stronger for sites in southern China $\left(<34^{\circ} \mathrm{N}\right.$; $R=0.3-0.6)$ than in northern China $(R=0.1-0.3)$ because of weaker retrieval sensitivity and larger upper tropospheric variability in the north. Ozonesonde data show that much of the variability of OMI ozone over southern China in sum-
\end{abstract}

mer is driven by the boundary layer. Comparison of 20052009 and 2013-2017 OMI data indicates that mean summer afternoon surface ozone in southern China (including urban and rural regions) has increased by $3.5 \pm 3.0 \mathrm{ppb}$ over the 8 year period and that the number of episode days per summer has increased by $2.2 \pm 0.4$ (as diagnosed by an extreme value model), generally consistent with the few long-term surface records. Ozone increases have been particularly large in the Yangtze River Delta and in the Hubei, Guangxi and Hainan provinces.

\section{Introduction}

Ozone in surface air is harmful to public health (Bell et al., 2004). It is produced by photochemical oxidation of volatile organic compounds (VOCs) in the presence of nitrogen oxides $\left(\mathrm{NO}_{\mathrm{x}} \equiv \mathrm{NO}+\mathrm{NO}_{2}\right)$. Both VOCs and $\mathrm{NO}_{x}$ are emitted in large amounts in polluted regions by fuel combustion and industry. Ozone pollution is a particularly severe problem in China, where the air quality standard of $82 \mathrm{ppb}$ (maximum $8 \mathrm{~h}$ daily average) is frequently exceeded (Wang et al., 2017). Observations in eastern China have reported increasing ozone trends of $1-3 \mathrm{ppb} \mathrm{a}^{-1}$ over the past decade (Sun et al., 2016; Gao et al., 2017; Ma et al., 2017; Li et al., 2019). The surface observations were very sparse until 2013, when 
data from a national network of $\sim 1000$ sites operated by China's Ministry of Ecology and Environment (MEE) started to become available. Here we use the MEE network data to evaluate the ability of the space-based Ozone Monitoring Instrument (OMI) to observe ozone pollution in China, and we use the OMI data going back to 2005 to infer long-term ozone pollution trends.

OMI measures atmospheric ozone absorption by solar backscatter in the UV (270-365 nm) (Levelt et al., 2006). It follows a long lineage of UV satellite instruments (Total Ozone Mapping Spectrometer series, TOMS, starting in 1979; Global Ozone Monitoring Experiment series ,GOME, starting in 1995) directed primarily at monitoring the total ozone column. Retrieval of tropospheric ozone (only $\sim 10 \%$ of the column) from these instruments has mostly been done in the past by subtracting independent satellite measurements of stratospheric ozone (Fishman et al., 1987; Ziemke et al., 2011) or using the convective cloud differential method (Ziemke et al., 1998, 2019). OMI has sufficiently fine spectral resolution to allow direct retrieval of tropospheric ozone, although the sensitivity decreases strongly toward the surface because of Rayleigh scattering (Liu et al., 2010). The direct retrieval typically provides one piece of information for the tropospheric ozone column weighted towards the middle troposphere (Zhang et al., 2010).

A number of previous studies have shown that satellite observations of ozone can detect boundary layer ozone pollution events (Fishman et al., 1987; Shim et al., 2009; Eremenko et al., 2008; Hayashida et al., 2008), including for Chinese urban plumes (Kar et al., 2010; Hayashida et al., 2015; Gaudel et al., 2018; Dufour et al., 2018). Even if sensitivity to the boundary layer is low, the enhancements can be sufficiently large to enable detection. However, no quantitative comparison of the satellite data to surface observations has so far been done. Surface ozone network data are available in the US and Europe but levels are generally too low to enable effective comparison. Ozone levels in China are much higher (Lu et al., 2018). The high density of the MEE network, combined with vertical profile information from ozonesondes and aircraft, provides a unique opportunity for evaluating quantitatively the ability of OMI to observe ozone pollution.

\section{Data and methods}

We use the OMI ozone profile retrieval (PROFOZ v0.9.3, level 2) product (Liu et al., 2010; Kim et al., 2013; Huang et al., 2017, 2018) from the Smithsonian Astrophysical Observatory (SAO). OMI is in polar sun-synchronous orbit with a 13:30 local observation time and provides daily global mapping with $13 \times 24 \mathrm{~km}^{2}$ nadir pixel resolution (Levelt et al., 2006). Partial ozone columns are retrieved by PROFOZ for 24 vertical layers, of which 3-7 are in the troposphere with pressure levels dependent on tropopause and surface pressure
(Liu et al., 2010). The retrieval uses a Bayesian optimization algorithm with prior information from the McPeters et al. (2007) climatology varying only by latitude and month. Averaging kernel matrices quantifying retrieval sensitivity are provided for individual retrievals. The trace of the averaging kernel matrix below a given retrieval pressure (degrees of freedom for signal or DOFS) estimates the number of independent pieces of information on the ozone profile below that pressure. The DOFS for the tropospheric ozone column in summer as retrieved by PROFOZ is about 1 (Zhang et al., 2010). The PROFOZ tropospheric retrievals have been successfully validated with ozonesonde data (Huang et al., 2017).

We focus on summer when ozone pollution in China is most severe and when OMI has the strongest sensitivity (Zhang et al., 2010). Since 2009, certain cross-track OMI observations have degraded because of the so-called row anomaly (Kroon et al., 2011; Huang et al., 2017, 2018). We only use pixels that (1) pass the reported quality checks, (2) have a cloud fraction less than 0.3, and (3) have a solar zenith angle less than $60^{\circ}$.

The DOFS below $400 \mathrm{hPa}$ over eastern China are in the range 0.3-0.6 (Fig. 1a). The DOFS is higher in the south than in the north due to higher solar elevation in the south, and higher over China than in background air at the same latitude due to higher ozone abundances. We use DOFS $>0.3$ in Fig. 1a as criterion for further analysis; this excludes northern and western China. Even though a DOFS of 0.3 is still low, it is based on the prior estimate of low boundary layer ozone in the McPeters et al. (2007) zonal mean climatology. As we will see, the retrieval is sensitive to ozone enhancements in the boundary layer when these are sufficiently high.

The prior estimate from McPeters et al. (2007) includes a latitudinal gradient of ozone concentrations that may be retained in the retrieval. To remove this background gradient and also any long-term uniform drift in the data, we subtract the monthly mean Pacific background $\left(150^{\circ} \mathrm{E}-150^{\circ} \mathrm{W}\right)$ from the OMI data over China for the corresponding latitude and month. The residual defines an OMI enhancement over China that we use for further analysis. This subtraction requires that we use a common pressure range for the OMI observations over China and the Pacific, but the OMI retrievals have variable pressure ranges depending on the local tropopause and surface pressure (Liu et al., 2010). The three lowest layers in the retrieval (L24-L22) have pressure ranges of approximately $1000-700,700-500$ and $500-350 \mathrm{hPa}$ for a column based at sea level, and all contain some information on boundary layer ozone (Fig. S1). Here we choose the pressure range $850-400 \mathrm{hPa}$ to define the OMI enhancement relative to the Pacific background and compute OMI columns for that pressure range by weighting the local L24-22 retrievals. Using $850 \mathrm{hPa}$ as a bottom pressure avoids complications from variable topography in eastern China. The $850-400 \mathrm{hPa}$ retrievals capture all of the OMI sensitivity below $850 \mathrm{hPa}$ in any case. We examined different spatial and temporal aver- 
Summer (JJA) 2013-2017 ozone over China from the MEE network and the OMI instrument

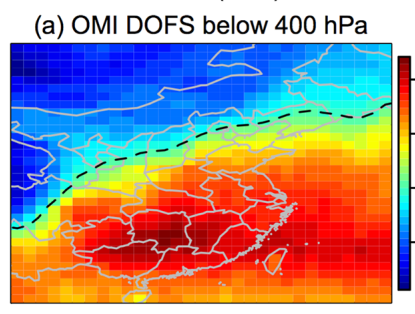

(d) Mean OMI ozone enhancement

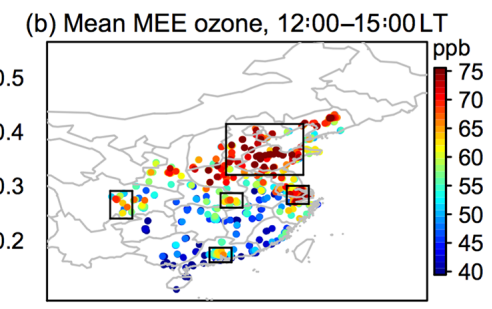

(e) Mean MEE vs. OMl enhancement

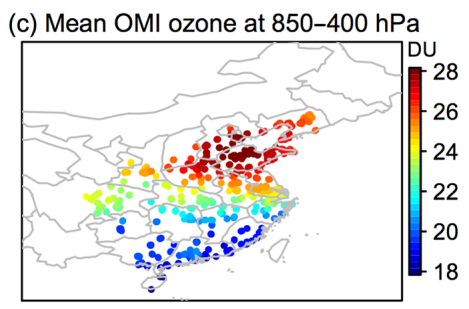

(f) Daily correlation, MEE vs. OMI
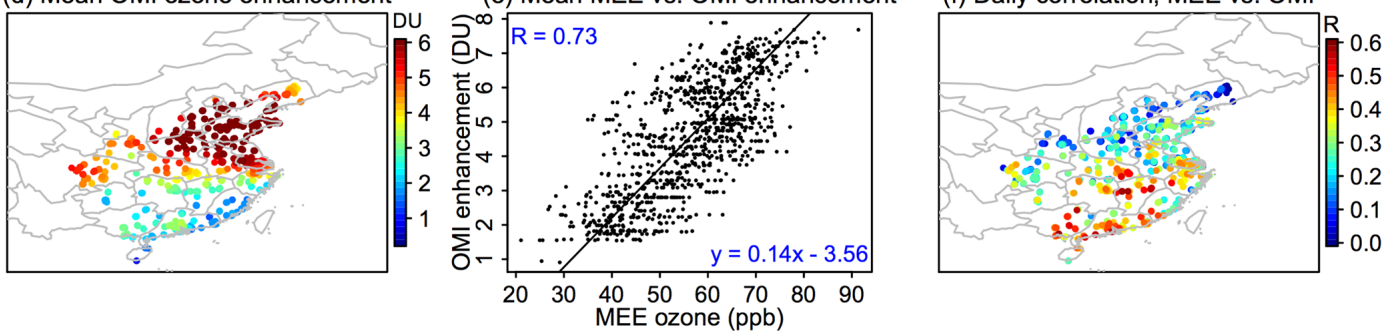

Figure 1. Summertime observations of ozone over China (JJA 2013-2017) from the MEE surface network and the OMI satellite instrument. (a) Mean degrees of freedom for signal (DOFS) of OMI ozone retrievals below $400 \mathrm{hPa}$. We limit our attention to the China domain with DOFS $>0.3$ (south of dashed line) and to sites with at least 100 concurrent surface and OMI observations for the 2013-2017 period. (b) Mean midday (12:00-15:00 local time) ozone concentrations from the MEE surface network. Rectangles identify high-ozone regions discussed in the text including Beijing-Tianjin-Hebei (BTH, $114-121^{\circ} \mathrm{E}$ and $\left.34-41^{\circ} \mathrm{E}\right)$, Yangtze River Delta (YRD, $119.5-121.5^{\circ} \mathrm{E}$ and $\left.30-32.5^{\circ} \mathrm{E}\right)$,

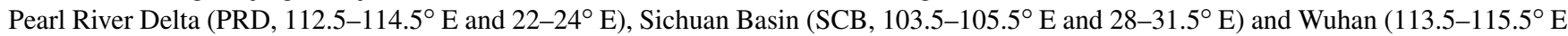
and $29.5-31.5^{\circ}$ E). (c) Mean OMI partial columns at 850-400 hPa. (d) Mean OMI ozone enhancements at 850-400 hPa after subtraction of the latitude-dependent mean background over the Pacific $\left(150^{\circ} \mathrm{E}-150^{\circ} \mathrm{W}\right)$. (e) Spatial correlation of mean JJA $2013-2017$ MEE ozone with the OMI ozone enhancement at $850-400 \mathrm{hPa}$. The correlation coefficient and the fitted reduced-major-axis (RMA) regression equation are shown inset. (f) Temporal correlation coefficients $(R)$ of daily MEE surface ozone with OMI at individual sites, measuring the ability of OMI to capture the day-to-day variability of surface ozone.

aging domains for the North Pacific background and found little effect on the residual.

We compare the OMI ozone enhancements to ozone measurements from surface sites, ozonesondes and aircraft. We use surface ozone measurements from the MEE network available for 2013-2017 (http://datacenter.mep.gov.cn/index, last access: March 2018). We select the summer (JJA) data at 12:00-15:00 local solar time (LT), corresponding to the OMI overpass. The network had 450 sites in 2013 and 1500 sites as of 2017, most located in large cities. We also use 20052016 summertime ozonesonde data at 12:00-15:00 LT for Hanoi $\left(21.0^{\circ} \mathrm{N}, 105.8^{\circ} \mathrm{E}\right)$, Hong Kong $\left(22.3^{\circ} \mathrm{N}, 114.2^{\circ} \mathrm{E}\right)$, Naha $\left(26.2^{\circ} \mathrm{N}, 127.7^{\circ} \mathrm{E}\right)$, Tsukuba $\left(36.1^{\circ} \mathrm{N}, 140.1^{\circ} \mathrm{E}\right)$ and Sapporo $\left(43.1^{\circ} \mathrm{N}, 141.3^{\circ} \mathrm{E}\right)$, available from the World Ozone and Ultraviolet Radiation Data Centre (WOUDC) (http:// woudc.org/, last access: March 2018). We further use takeoff and landing vertical profiles at 12:00-15:00 LT over East Asia from the In-Service Aircraft for the Global Observing System (IAGOS, http://www.iagos-data.fr/, last access: February 2019). For evaluating the long-term surface ozone trends inferred from OMI, we use 2005-2014 trend statistics for maximum daily $8 \mathrm{~h}$ average (MDA8) ozone from the Tropospheric Ozone Assessment Report (TOAR) (Schultz et al., 2017). We also have 2005-2017 JJA 12:00-15:00 LT mean ozone at the Hok Tsui station in Hong Kong (Wang et al., 2009).

\section{Inference of surface ozone from OMI observations}

Figure $1 \mathrm{~b}$ shows the mean midday (12:00-15:00 LT) surface ozone for the summers of 2013-2017 as measured by the MEE network. Concentrations exceed $70 \mathrm{ppb}$ over most of the North China Plain with particularly high values in the Beijing-Tianjin-Hebei (BTH) megacity cluster. Values are also high in the Yangtze River Delta (YRD), Pearl River Delta (PRD), Sichuan Basin (SCB) and the city of Wuhan in central China. High values extend to the region west of the North China Plain, which is less densely populated but has elevated terrain.

OMI mean ozone abundances at $850-400 \mathrm{hPa}$ for the summers of 2013-2017 are shown in Fig. 1c. Values are partial column concentrations in Dobson units $(1 \mathrm{DU}=2.69 \times$ $10^{16}$ molecules per square centimeter). After subtracting the North Pacific background for the corresponding latitude in month, we obtain the OMI ozone enhancements shown in Fig. 1d. The spatial correlation coefficient between the OMI ozone enhancements and the MEE surface network is $R=$ 0.73 over eastern China. The correlation is driven in part 


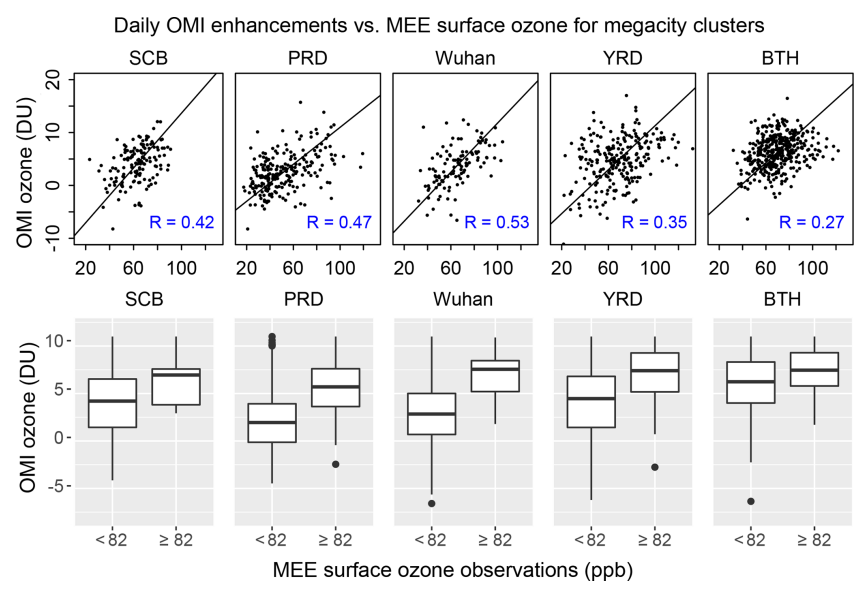

Figure 2. Ability of daily OMI observations to detect high-ozone episodes in the five megacity clusters of Fig. 1. Daily surface afternoon (12:00-15:00 local time) observations from the MEE network in summer (JJA) 2013-2017 averaged over the megacity clusters are compared to the corresponding OMI enhancements relative to the Pacific background. The top panels show the correlations in the daily data, with correlation coefficients inset. Reduced-major-axis (RMA) linear regression lines are also shown. The bottom panels show the distributions of OMI enhancements for episode ( $\geq 82 \mathrm{ppb}$ ) and non-episode $(<82 \mathrm{ppbv})$ days. The top and bottom of each box are the 25 th and 75 th percentiles, the centerline is the median, the vertical bars are the 2nd and 98th percentiles, and the dots are outliers.

by the latitudinal gradient but also by the enhancements in the large megacity clusters identified as rectangles in Fig. 1 b. Thus the correlation coefficient is $R=0.55$ for the $26-34^{\circ} \mathrm{N}$ latitude band including YRD, SCB and Wuhan. Figure 1e shows the corresponding scatterplot and the reduced-majoraxis (RMA) regression relating the OMI enhancement $\Delta \Omega$ to the 12:00-15:00 LT surface concentration $\left[\mathrm{O}_{3}\right]$ (the slope is $\left.0.14 \mathrm{DU} \mathrm{ppb}^{-1}\right)$. From there one can estimate multiyear average surface ozone (ppb) on the basis of the observed OMI enhancement (DU) as

$\left[\mathrm{O}_{3}\right]=6.9 \Delta \Omega+24.6 \pm 8.4$

where the error standard deviation (precision) of $8 \mathrm{ppb}$ is inferred from the scatterplot. With such a precision, OMI can provide useful information on mean summer afternoon levels of surface ozone in polluted regions.

Capturing the day-to-day variability of surface ozone leading to high-ozone pollution episodes is far more challenging because of noise in individual retrievals. Figure 1f shows the OMI vs. MEE temporal correlation for the daily data. Correlation coefficients are consistently positive and statistically significant, but relatively weak. They are higher in southern China $(R=0.3-0.6)$ than in northern China $(R=0.1-$ $0.3)$, consistent with the pattern of OMI information content (DOFS) in Fig. 1a. This implies that OMI can only provide statistical rather than deterministic temporal information on ozone pollution episodes, and it may be more useful in southern than in northern China. We return to this point in Sect. 4.

Figure 2 (top panel) shows the relationship of OMI enhancements with daily MEE surface ozone concentrations averaged spatially in each of the five megacity clusters identified in Fig. 1. Consistent with the distribution of DOFS (Fig. 1a), the correlations are higher in PRD, SCB and Wuhan $(0.42-0.53, p<0.05)$ than in YRD $(0.35, p<0.05)$ and lowest in BTH $(0.27, p<0.05)$. The correlations indicate some capability for OMI to predict ozone daily variability on a statistical basis. The reduced-major-axis (RMA) regression slopes are consistent across the five regions and average $0.15 \mathrm{DU} \mathrm{ppb}^{-1}$. We define an ozone episode day by afternoon concentrations exceeding $82 \mathrm{ppb}$, corresponding to the Chinese air quality standard. The bottom panels of Fig. 2 compare the OMI ozone enhancements between episode and non-episode days as measured by the surface network. OMI is significantly higher $(p<0.05)$ on episode days for all five regions.

\section{OMI boundary layer sensitivity inferred from ozonesondes}

The correlation of OMI with the MEE surface ozone data likely does not reflect a direct sensitivity of OMI to surface ozone, which is very weak, but rather a sensitivity to boundary layer ozone extending up to a certain depth and correlated with surface ozone. We examined in more detail the sensitivity of OMI to boundary layer ozone and its dayto-day variability by comparing to summertime 2005-2016 Hong Kong ozonesonde data. Figure 3 a shows the measured ozonesonde profiles (in ppb) mapped on a $100 \mathrm{hPa}$ grid and selecting only the days when concurrent OMI retrievals are available $(n=57)$. The boundary layer ozone $(950-850 \mathrm{hPa})$ in the ozonesonde data has large day-to-day variability, ranging from 20 to $120 \mathrm{ppb}$ with a mean of $47 \mathrm{ppb}$. The variability in the free troposphere is much less.

Figure $3 b$ shows the ozonesonde data smoothed by the OMI averaging kernel sensitivities for the corresponding retrievals. The retrievals over Hong Kong have a mean DOFS of 0.46 below $400 \mathrm{hPa}$. We see from Fig. $3 \mathrm{c}$ that the OMI information is weighted toward the free troposphere but there is sensitivity in the boundary layer, and since boundary layer variability is much larger it can make a major contribution to OMI variability. The L23 ozone smoothed from the ozonesonde data in Fig. $3 \mathrm{~b}$ has a correlation coefficient of 0.75 with the $950-850 \mathrm{hPa}$ ozone in the original data. The temporal correlation coefficients of the OMI retrievals at different levels with the $950-850 \mathrm{hPa}$ ozonesonde data are given in Fig. 3d. The correlation coefficient with L23 OMI ozone is $0.51(p<0.05)$, and the correlation coefficient with the 850 $400 \mathrm{hPa}$ OMI ozone constructed by weighting the L24-L23L22 retrievals is 0.50 . Figure $3 \mathrm{e}$ shows a scatterplot of the latter. We see that high-ozone episodes in the $950-850 \mathrm{hPa}$ 


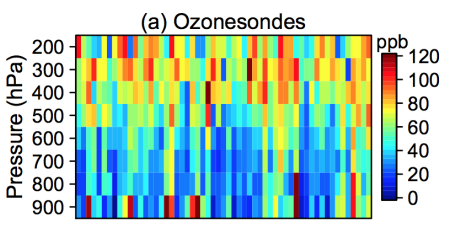

Ozone vertical profiles Hong Kong, JJA 2005-2016
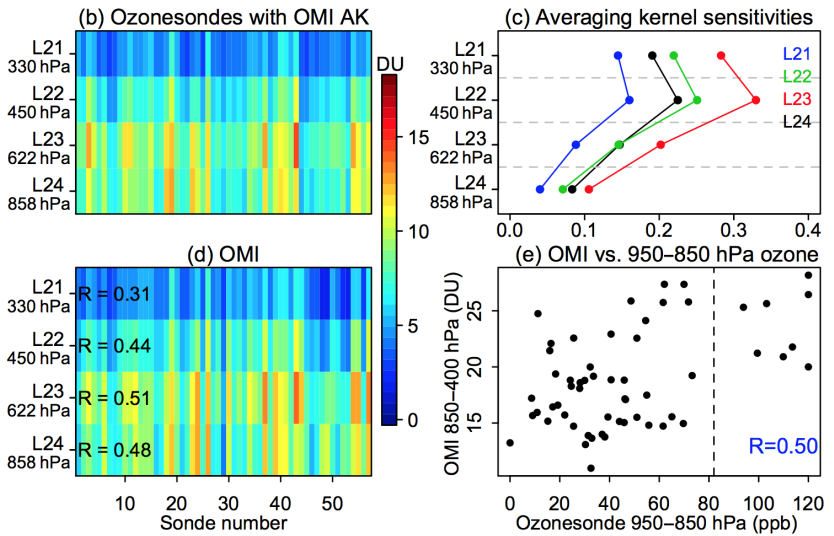

Figure 3. Ozone vertical profiles over Hong Kong in summer (JJA) 2015-2016. (a) Ozonesonde data coincident with OMI observations $(n=57)$, averaged over a $100 \mathrm{hPa}$ grid and arranged in chronological order. (b) The same ozonesonde data but smoothed by the OMI averaging kernels. Mean pressures for each OMI retrieval level are indicated. (c) Mean averaging kernel sensitivities for each OMI retrieval level, as described by the rows of the averaging kernel matrix; values are shown for August 2015 but are similar in other summer months and years. The dashed lines are boundaries between retrieval levels. (d) OMI ozone observations coincident with the ozonesondes. The correlations of unsmoothed 950$850 \mathrm{hPa}$ ozonesonde data with the OMI retrievals for different levels are shown inset. (e) Relationship of unsmoothed $950-850 \mathrm{hPa}$ ozonesonde data and OMI $850-400 \mathrm{hPa}$ ozone. The correlation is shown inset. The dashed line corresponds to the Chinese ozone air quality standard (82 ppb).

sonde data are systematically associated with high OMI values, though the converse does not always hold because free tropospheric enhancements affecting OMI can also occur. For the eight boundary layer episode days $(>82 \mathrm{ppb})$, the average OMI $850-400 \mathrm{hPa}$ ozone is $23.7 \pm 3.1 \mathrm{DU}$, significantly higher than for the non-episode days (18.2 $\pm 4.1 \mathrm{DU})$. The Hong Kong ozonesonde data thus indicate that OMI can quantify the frequency of high-ozone episodes in the boundary layer even if it may not be reliable for individual events.

We applied the same daily correlation analysis to the other ozonesonde datasets and IAGOS aircraft measurements during 2005-2017 summers. For the 54 IAGOS vertical profiles coincident with OMI observations, the correlation coefficient of the $950 \mathrm{hPa}$ in situ ozone and $850-400 \mathrm{hPa}$ OMI ozone is $R=0.59(p<0.05)$ (Fig. S2). For the five ozonesonde sites with long-term observations, the correlation coefficients are 0.4-0.6 for Hanoi, Hong Kong and Naha (south of $30^{\circ} \mathrm{N}$ ), and $0-0.3$ for Sapporo and Tsukuba (north of $35^{\circ} \mathrm{N}$ )

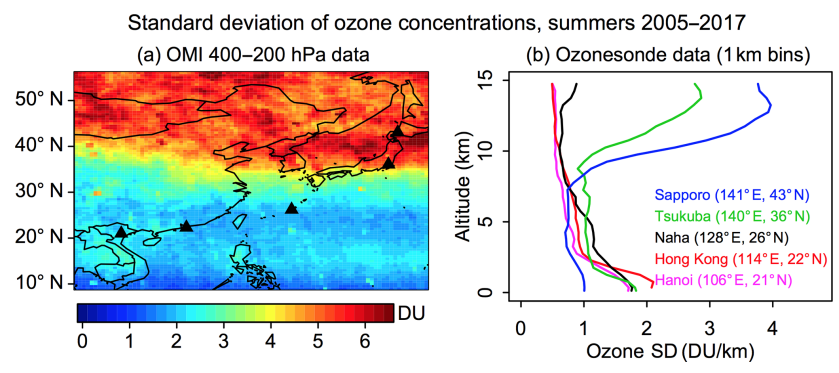

Figure 4. (a) Standard deviation of daily OMI 400-200 hPa ozone in East Asia during the 2005-2017 summers. The triangles are the locations of ozonesonde sites with observations during this period. (b) Vertical profiles of daily ozone standard deviation in $1 \mathrm{~km}$ bins (DU km ${ }^{-1}$ ) in the ozonesonde data for the 2005-2017 summers.

(Fig. S3), consistent with the patterns of daily correlations for the MEE data (Fig. 1f).

The correlation between boundary layer ozone pollution and the OMI ozone retrievals could be due in part to correlation between boundary layer and mid-tropospheric ozone, considering that both tend to be driven by the same weather systems. We used the ozonesonde data to examine what correlation with boundary layer $(950-850 \mathrm{hPa})$ ozone would be observed if OMI were sensitive only to the free troposphere at $\sim 500 \mathrm{hPa}$ (where its sensitivity is maximum, Fig. 3c) and not to the boundary layer. In that case the correlation coefficient $R_{1,3}$ of boundary layer ozone and the OMI $850-400 \mathrm{hPa}$ retrievals would be given by (Vos, 2009)

$R_{1,3}=R_{1,2} R_{2,3} \pm \sqrt{\left(1-R_{1,2}^{2}\right)\left(1-R_{2,3}^{2}\right)}$,

where $R_{1,2}$ is the correlation coefficient between boundary layer and $500 \mathrm{hPa}$ ozone in the ozonesonde data and $R_{2,3}$ is that between $500 \mathrm{hPa}$ ozone and the OMI $850-400 \mathrm{hPa}$ retrievals. As seen from Fig. S4, $R_{1,3}$ at the five sonde sites is only $\sim 0.2$, implying that direct sensitivity to the boundary layer dominates the correlation of OMI with surface ozone at least in southern China. Further evidence for this is the ability of OMI to detect the ozone enhancements in megacity clusters (Fig. 1).

We find that the low correlation of OMI with boundary layer ozone in the northern ozonesonde data is due not only to the low DOFS but also to a large variability of ozone in the upper troposphere. Figure 4 (left panel) shows the standard deviation of daily OMI 400-200 hPa ozone during 20052017 summers, indicating that upper tropospheric ozone has much higher variability in the north $\left(>34^{\circ} \mathrm{N}\right)$ than in the south. This is related to the location of the jet stream and more active stratospheric influence (Hayashida et al., 2015). Figure 4 (right panel) displays the vertical profiles of ozone standard deviations for the five ozonesonde sites. For the two sites north of $34^{\circ} \mathrm{N}$, the ozone variability becomes very large above $8 \mathrm{~km}$. Since the OMI $850-400 \mathrm{hPa}$ retrieval also contains information from above $400 \mathrm{hPa}$, this upper tropo- 
spheric variability causes a large amount of noise that masks the signal from boundary layer variability. For the three sites south of $34^{\circ} \mathrm{N}$, the ozone variability in the boundary layer is much higher than in the free troposphere, and the upper tropospheric ozone variability still remains low even above $8 \mathrm{~km}$. In the rest of this paper we focus our attention on ozone episodes and the long-term trends in southern China (south of $34^{\circ} \mathrm{N}$ ).

\section{Using extreme value theory to predict the occurrence of high-ozone episodes from OMI data}

We construct a point process (PP) model from extreme value theory (Cole, 2001) to estimate the likelihood of surface ozone exceeding a high-ozone threshold $u$ (here $u=82 \mathrm{ppb}$ at 12:00-15:00 LT) at a given site $i$ and day $t$ given the observed OMI ozone enhancement $x_{i, t}$ for that day. The model describes the high tail of the ozone probability density function (pdf) as a Poisson process limit, conditioned on the local OMI observation. Such a model has been used previously to relate the probability of extreme air pollution conditions to meteorological predictor variables (Rieder et al., 2013; Shen et al., 2016, 2017; Pendergrass et al., 2019), but here we use the OMI enhancement as predictor variable. We fit the model to all daily concurrent observations of surface ozone and OMI ozone enhancements for the ensemble of eastern China sites south of $34^{\circ} \mathrm{N}$ in Fig. 5 (90601 observations for summers 2013-2017). The probability of exceeding the threshold at a site $i$ should depend not only on $x_{i, t}$ but also on its time-averaged value $\bar{x}_{i}$, because a high value of $\bar{x}_{i}$ means that a higher $x_{i, t}$ is less anomalous and more likely to represent an actual ozone exceedance than for a site with low $\bar{x}_{i}$. Thus the model has two predictor variables, $x_{i, t}$ and $\bar{x}_{i}$.

Details of the PP model can be found in Cole (2001). The model fits three parameters that control the shift, spread and shape of the high-tail pdf. The fit minimizes a cost function $L$ given by

$$
L=\prod_{i=1}^{m} L_{i}\left(\mu_{i}, \sigma_{i}, \xi\right)
$$

with

$$
\begin{aligned}
& L_{i}\left(\mu_{i}, \sigma_{i}, \xi\right)= \\
& \qquad \exp \left\{-\frac{1}{n_{a}} \sum_{t=1}^{n}\left[1+\frac{\xi\left(u-\mu_{i}\right)}{\sigma_{i, t}}\right]^{-1 / \xi}\right\} \\
& \quad \prod_{t=1}^{n}\left\{\frac{1}{\sigma_{i, t}}\left[1+\frac{\xi\left(y_{i, t}-\mu_{i}\right)}{\sigma_{i, t}}\right]^{-1 / \xi-1}\right\}^{I\left[y_{i, t}>u\right]}, \\
& \mu_{i}=\alpha_{0}+\alpha_{1} \bar{x}_{i}, \\
& \bar{x}_{i}=\frac{1}{n} \sum_{t=1}^{n} x_{i, t}
\end{aligned}
$$

Evaluation of extreme value point process model for high-ozone episodes (a) Probability of exceeding $82 \mathrm{ppb}$ in the daily 12:00-15:00 LT data

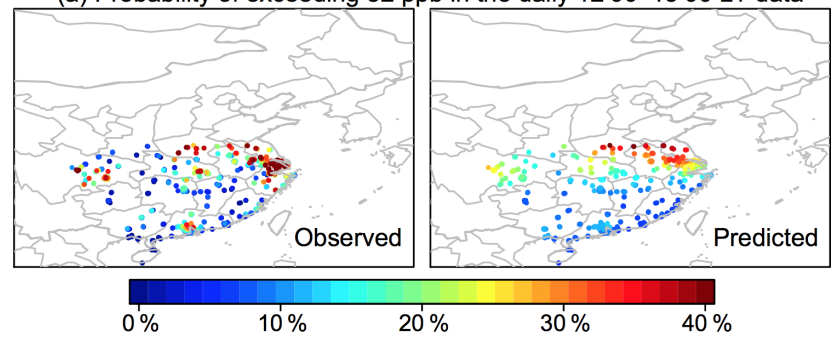

(b) Probabilities of exceeding $82-130 \mathrm{ppb}$ ozone thresholds

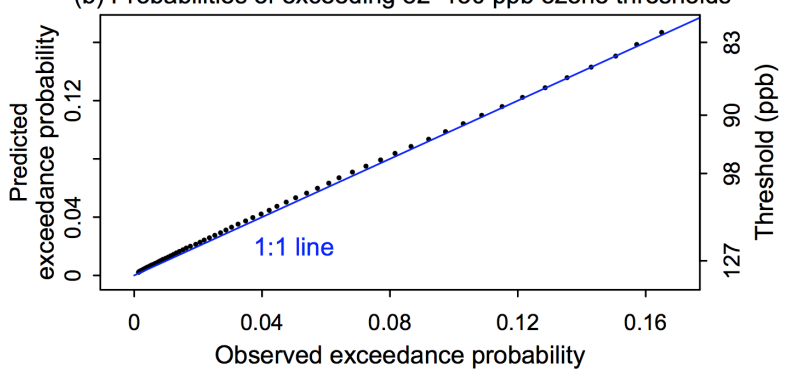

Figure 5. Evaluation of the extreme value point process (PP) model for predicting the probability of occurrence of summertime highozone episodes from the OMI daily data. The episodes are defined by exceedance of a given ozone threshold in the $3 \mathrm{~h}$ average data at 12:00-15:00 local time. (a) Observed and predicted probability of ozone episode days exceeding a $82 \mathrm{ppb}$ threshold. The predicted probability is calculated from Eq. (8). (b) Observed and predicted probabilities of exceeding higher thresholds from 82 to $130 \mathrm{ppb}$.

$\sigma_{i, t}=\exp \left(\beta_{0}+\beta_{1} x_{i, t}\right)$

Here $L_{i}\left(\mu_{i}, \sigma_{i}, \xi\right)$ is the cost function for site $i$ and $L$ is for the total cost function for all $m$ sites, $y_{i, t}$ is the daily 12:00-15:00 LT MEE surface ozone from each individual site $i$ on day $t, n_{a}=92$ is the number of days in summer, $\mu_{i}$ is the location parameter for site $i$ conditioned on the 2013-2017 summertime mean OMI enhancements $\bar{x}_{i}, \sigma_{i, t}$ is the scale parameter conditioned on the local OMI ozone enhancements $x_{i, t}, \xi$ is the shape factor and $I\left[y_{i, t}>u\right]$ is 1 if observed ozone is above the threshold and 0 if otherwise. Minimization of the cost function optimizes the values of the parameters $\alpha_{0}, \alpha_{1}, \beta_{0}, \beta_{1}$ and $\xi$ given the $90601\left(x_{i, t}, y_{i, t}\right)$ data pairs. The resulting values are $\alpha_{0}=103 \mathrm{ppb}, \alpha_{1}=6.0$, $\beta_{0}=2.8 \mathrm{ppb}, \beta_{1}=-0.033$ and $\xi=-0.12$. The probability of daily ozone exceeding the threshold $u$ is then calculated as

$p\left(y_{i, t} \geq u \mid x_{i, t}\right)=\frac{1}{n_{a}}\left[1+\xi\left(\frac{u-\mu_{i}}{\sigma_{i, t}}\right)\right]^{-1 / \xi}$.

The model is optimized using the extRemes package in R (Gilleland and Katz, 2011). We performed a 10-fold cross validation of the model, in which we partitioned the sites into 10 equal subsets and repeatedly used one subset as testing 
data and the rest as training data. The results show that the predicted fraction of ozone episodes resembles that observed, with a spatial correlation of 0.62 (Fig. 5a). The model tends to underestimate the probability of episodes in polluted regions due to the noise of daily OMI ozone. The $82 \mathrm{ppb}$ corresponds to the 84 th percentile of the data, which is a relatively low threshold for application of extreme value theory. However, we find that the model can also accurately estimate the probability of exceedance above higher thresholds (Fig. 5b) for the ensemble of eastern China sites south of $34^{\circ} \mathrm{N}$, which confirms the property of threshold invariance of an extreme value model (Cole, 2001). We also tested the model with uniform location or scale factors, but neither could reproduce the observed spatial distribution of ozone episodes.

\section{2005-2017 trends in surface ozone inferred from OMI data}

We used the long-term OMI ozone record for 2005-2017 to infer trends in surface ozone over southern China, not including any tropospheric background trends (removed by our subtraction of the North Pacific). Figure 6 shows the changes between 2005-2009 and 2013-2017 (an 8-year period) in mean summer afternoon ozone concentrations and in the number of high-ozone episode days per summer. Here we have extended the trend analysis to Taiwan because of the opportunity to compare to surface records. The changes in mean summer afternoon ozone concentrations are obtained from the difference in the mean OMI ozone enhancements between the two time periods (Fig. S5) and applying Eq. (1). The changes in the number of high-ozone episode days per summer are obtained by applying the probability of exceeding $82 \mathrm{ppb}$ (Eq. 8) to each pair of 5 years of OMI data. When averaged across southern China (including urban and rural regions), the mean summer afternoon ozone concentrations have increased by $3.5 \pm 3.0 \mathrm{ppb}$ between the two periods (Fig. 6a), and the number of ozone episodes ( $>82 \mathrm{ppb}$ ) has increased by $2.2 \pm 0.4 \mathrm{~d}$ per summer (Fig. 6b). Conditions have become particularly worse in YRD and in Hubei, Guangxi and Hainan provinces where the number of highozone days per summer has increased by more than five.

We compared the OMI trends in Fig. 6 to the trends of MDA8 ozone and number of high-ozone days reported by the long-term TOAR sites (Schultz et al., 2017) and our own analysis for the Hok Tsui station in Hong Kong (Wang et al., 2009). For Lin'an, Hong Kong and the five sites in Taiwan (we report the mean value here), the changes of mean ozone concentrations from 2005-2009 to 2013-2017 are 1.1 \pm 3.6 , $2.3 \pm 3.3$ and $-0.18 \pm 2.9 \mathrm{ppb}$ as estimated from OMI, compared to $0.7 \pm 3.6,5.6 \pm 3.9$ (or 5.8 \pm 1.3 in Hok Tsui station) and $-0.75 \pm 2.5 \mathrm{ppb}$ for MDA8 ozone at the TOAR sites. The changes in the number of ozone episodes per summer are $1.2 \pm 0.7,1.9 \pm 0.24$ and $-0.17 \pm 0.14 \mathrm{~d}$ in OMI, compared to $2.1 \pm 4.4,1.8 \pm 1.7$ (or $2.1 \pm 1.1$ in Hok Tsui station) and
Changes in summertime surface ozone pollution inferred from OMI (2005-2009 to 2013-2017) (a) Mean afternoon ozone

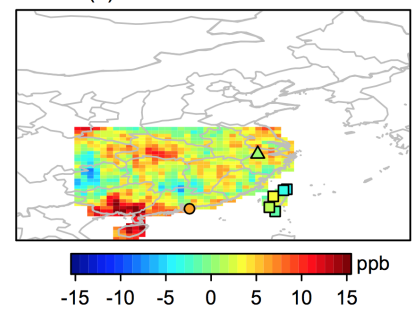

(b) Number of $>82 \mathrm{ppb}$ days per summer

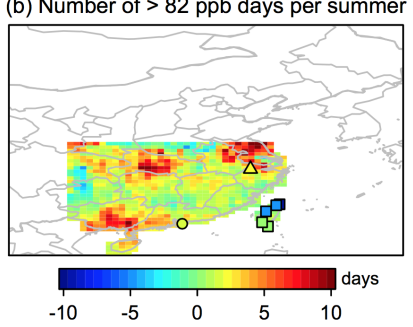

Figure 6. Changes in surface ozone pollution between the 20052009 and 2013-2017 periods (separated by 8 years) as inferred from OMI afternoon observations at around 13:30 local time. (a) Change in mean summer afternoon concentrations, obtained from the difference in the mean OMI ozone enhancements and applying Eq. (1). Also shown with symbols are observed changes in mean MDA8 ozone from in situ observations in Lin'an, Hong Kong and Taiwan reported by TOAR (Schultz et al., 2017). Because the TOAR observations are only reported for 2005-2014, we estimate the changes from 2005-2009 to 2013-2017 on the basis of the reported linear trends during 2005-2014 ( $\left.\mathrm{ppba}^{-1}\right)$. (b) Change in the number of high-ozone days ( $>82 \mathrm{ppb}$ ) per summer, calculated by applying the probability of exceeding $82 \mathrm{ppb}$ (Eq. 8) to the daily OMI enhancements. Also shown with symbols are observed changes of the number of days with MDA8 ozone exceeding $80 \mathrm{ppb}$ at the TOAR sites, similarly adjusted as the change from 2005-2009 to 2013-2017.

$-3.5 \pm 1.8 \mathrm{~d}$ at the TOAR sites. The standard errors are obtained by applying a parametric bootstrap method. The OMI inferred trends are generally consistent with the long-term records available from surface sites.

\section{Discussion and conclusions}

Satellite observations of tropospheric ozone in the UV could provide an indicator of surface ozone pollution if the associated boundary layer enhancement is large enough. We presented a quantitative evaluation of this capability for OMI ozone retrievals in China by comparison to the extensive 2013-2017 ozone network data from China's Ministry of Ecology and Environment (MEE), together with vertical profiles from ozonesondes and aircraft. We went on to use the long-term OMI record (2005-2017) to infer surface ozone pollution trends over that period.

After subtracting the contribution from the North Pacific background, we find that the OMI enhancement over eastern China can reproduce the observed spatial distribution of multiyear mean summer afternoon ozone concentrations at the MEE sites, with a correlation coefficient $R=0.73$ and a precision of $8 \mathrm{ppb}$. Even though OMI has little sensitivity to surface ozone, the high-ozone levels seen at surface sites propagate deep enough in the boundary layer to be observed by OMI. Day-to-day correlation at individual sites is weaker $\left(R=0.1-0.3^{\circ} \mathrm{N}\right.$ of $34^{\circ} \mathrm{N}, 0.3-0.6^{\circ} \mathrm{S}$ of $\left.34^{\circ} \mathrm{N}\right)$ be- 
cause of noise in individual OMI retrievals. But we find that OMI is statistically enhanced in urban areas when surface ozone exceeds an $8 \mathrm{~h}$ maximum daily average (MDA8) value of $82 \mathrm{ppb}$ (the Chinese air quality standard).

To better understand the correlation of OMI with surface ozone we examined vertical ozone profiles from Hong Kong and other ozonesondes, and from the IAGOS commercial aircraft program. Some of the correlation is driven by similar meteorology influencing ozone in the mid-troposphere (where OMI sensitivity is maximum) and the boundary layer, but most of the correlation is driven by direct sensitivity to the boundary layer. The Hong Kong ozonesonde data also indicate that OMI can quantify the frequency of high-ozone episodes in the boundary layer even if it may not be reliable for individual events. In southern China $\left(<34^{\circ} \mathrm{N}\right)$, we find that ozone variability in the tropospheric column is dominated by the boundary layer, explaining the stronger correlations there. The lower correlation of OMI with surface ozone further north is due to large upper tropospheric variability in addition to lower sensitivity.

We went on to use the 2005-2017 OMI record to diagnose long-term trends of surface ozone in southern China $\left(<34^{\circ} \mathrm{N}\right)$. This involved the development of a point process model from extreme value theory to infer the probability of surface ozone exceeding $82 \mathrm{ppb}$ and higher thresholds on the basis of the daily observed OMI ozone enhancements. The OMI record shows a general increase across southern China (including urban and rural regions) from 2005-2009 to 2013-2017 (8-year period) in mean summertime afternoon ozone $(+3.5 \pm 3.0 \mathrm{ppb})$ and in the frequency of high-ozone episodes $(+2.2 \pm 0.4 \mathrm{~d}$ per summer). Increases are particularly large in the Yangtze River Delta and in Hubei, Guangxi and Hainan provinces. The trends are generally consistent with the few long-term records available from surface sites.

Our method for inferring ozone pollution and the frequency of high-ozone episodes from the OMI satellite data may be applied to other regions of the world where surface ozone is expected to be high but where in situ observations are lacking. The next generation of UV satellite instruments may improve this capability. The TROPOspheric Monitoring Instrument (TROPOMI) launched in October 2017 is now providing daily observations with $3.5 \times 7 \mathrm{~km}^{2}$ pixel resolution, much finer than OMI (Theys et al., 2017). The GEMS (Geostationary Environment Monitoring Spectrometer) instrument is expected to launch in late 2019 and will observe East Asia with an hourly frequency and sensitivity similar to OMI (Bak et al., 2013). The TEMPO (Tropospheric Emissions: Monitoring of Pollution) geostationary satellite instrument to be launched around 2020 over North America will have a spectral range extending to the visible Chappuis bands where ozone detection sensitivity remains high down to the surface (Zoogman et al., 2011, 2017). This should allow for improved observations of surface ozone, particularly where concentrations are not as high as they are presently in China.
Data availability. The OMI ozone data and surface measurements are available upon request.

Supplement. The supplement related to this article is available online at: https://doi.org/10.5194/acp-19-6551-2019-supplement.

Author contributions. LS and DJ designed the experiments and LS carried them out. XL and GH provided the satellite data. KL, HL and TW provided the surface observations. LS and DJ prepared the paper with contributions from all co-authors.

Competing interests. The authors declare that they have no conflict of interest.

Acknowledgements. This work was funded by the Harvard Global Institute (HGI), by the NASA Earth Science Division and by the Joint Laboratory for Air Quality and Climate (JLAQC) between Harvard and the Nanjing University for Information Sciences and Technology (NUIST).

Financial support. This research has been supported by the Harvard Global Institute (grant no. HGI373516).

Review statement. This paper was edited by Qiang Zhang and reviewed by three anonymous referees.

\section{References}

Bak, J., Kim, J. H., Liu, X., Chance, K., and Kim, J.: Evaluation of ozone profile and tropospheric ozone retrievals from GEMS and OMI spectra, Atmos. Meas. Tech., 6, 239-249, https://doi.org/10.5194/amt-6-239-2013, 2013.

Bell, M. L., McDermott, A., Zeger, S. L., Samet, J. M., and Dominici, F.: Ozone and short-term mortality in 95 US urban communities, 1987-2000, JAMA, 292, 2372-2378, 2004.

Coles, S. G.: An Introduction to Statistical Modeling of Extreme Values, Springer, New York, 2001.

Dufour, G., Eremenko, M., Beekmann, M., Cuesta, J., Foret, G., Fortems-Cheiney, A., Lachâtre, M., Lin, W., Liu, Y., Xu, X., and Zhang, Y.: Lower tropospheric ozone over the North China Plain: variability and trends revealed by IASI satellite observations for 2008-2016, Atmos. Chem. Phys., 18, 16439-16459, https://doi.org/10.5194/acp-18-16439-2018, 2018.

Eremenko, M., Dufour, G., Foret, G., Keim, C., Orphal, J., Beekmann, M., Bergametti, G., and Flaud, J.-M.: Tropospheric ozone distributions over Europe during the heat wave in July 2007 observed from infrared nadir spectra recorded by IASI, Geophys. Res. Lett., 35, L18805, https://doi.org/10.1029/2008GL034803, 2008.

Fishman, J., Vukovich, F. M., Cahoon, D. R., and Shipham, M. C.: The characterization of an air pollution episode using satellite 
total ozone measurements, J. Clim. Appl. Meteorol., 26, 16381654, 1987.

Gao, W., Tie, X., Xu, J., Huang, R., Mao, X., Zhou, G., and Chang, L.: Long-term trend of $\mathrm{O} 3$ in a mega City (Shanghai), China: Characteristics, causes, and interactions with precursors, Sci. Total. Environ., 603, 425-433, 2017.

Gaudel, A., Cooper, O. R., Ancellet, G., Barret, B., Boynard, A., Burrows, J. P., Clerbaux, C., Coheur, P. F., Cuesta, J., Cuevas Agulló, E., and Doniki, S.: Tropospheric Ozone Assessment Report: Present-day distribution and trends of tropospheric ozone relevant to climate and global atmospheric chemistry model evaluation, Elem. Sci. Anth., 6, 39, https://doi.org/10.1525/elementa.291, 2018.

Gilleland, E. and Katz, R. W.: New software to analyze how extremes change over time, Eos T. Am. Geophys. Un., 92, 13-14, https://doi.org/10.1029/2011EO020001, 2011.

Hayashida, S., Urita, N., Noguchi, K., Liu, X., and Chance, K.: Spatiotemporal Variation in Tropospheric Column Ozone over East Asia Observed by GOME and Ozonesondes, Sola, 4, 117-120, 2008.

Hu, L., Jacob, D. J., Liu, X., Zhang, Y., Zhang, L., and Kim, P. S.: Global budget of tropospheric ozone: evaluating recent model advances with satellite (OMI), aircraft (IAGOS), and ozonesonde observations, Atmos. Environ., 167, 323-334, 2017.

Huang, G., Liu, X., Chance, K., Yang, K., Bhartia, P. K., Cai, Z., Allaart, M., Ancellet, G., Calpini, B., Coetzee, G. J. R., CuevasAgulló, E., Cupeiro, M., De Backer, H., Dubey, M. K., Fuelberg, H. E., Fujiwara, M., Godin-Beekmann, S., Hall, T. J., Johnson, B., Joseph, E., Kivi, R., Kois, B., Komala, N., König-Langlo, G., Laneve, G., Leblanc, T., Marchand, M., Minschwaner, K. R., Morris, G., Newchurch, M. J., Ogino, S.-Y., Ohkawara, N., Piters, A. J. M., Posny, F., Querel, R., Scheele, R., Schmidlin, F. J., Schnell, R. C., Schrems, O., Selkirk, H., Shiotani, M., Skrivánková, P., Stübi, R., Taha, G., Tarasick, D. W., Thompson, A. M., Thouret, V., Tully, M. B., Van Malderen, R., Vömel, H., von der Gathen, P., Witte, J. C., and Yela, M.: Validation of 10-year SAO OMI Ozone Profile (PROFOZ) product using ozonesonde observations, Atmos. Meas. Tech., 10, 2455-2475, https://doi.org/10.5194/amt-10-2455-2017, 2017.

Huang, G., Liu, X., Chance, K., Yang, K., and Cai, Z.: Validation of 10-year SAO OMI ozone profile (PROFOZ) product using Aura MLS measurements, Atmos. Meas. Tech., 11, 17-32, https://doi.org/10.5194/amt-11-17-2018, 2018.

Kar, J., Fishman, J., Creilson, J. K., Richter, A., Ziemke, J., and Chandra, S.: Are there urban signatures in the tropospheric ozone column products derived from satellite measurements?, Atmos. Chem. Phys., 10, 5213-5222, https://doi.org/10.5194/acp-105213-2010, 2010.

Kim, P. S., Jacob, D. J., Liu, X., Warner, J. X., Yang, K., Chance, K., Thouret, V., and Nedelec, P.: Global ozone-CO correlations from OMI and AIRS: constraints on tropospheric ozone sources, Atmos. Chem. Phys., 13, 9321-9335, https://doi.org/10.5194/acp13-9321-2013, 2013.

Kroon, M., de Haan, J. F., Veefkind, J. P., Froidevaux, L., Wang, R., Kivi, R., and Hakkarainen, J. J.: Validation of operational ozone profiles from the Ozone Monitoring Instrument, J. Geophys. Res., 116, D18305, https://doi.org/10.1029/2010JD015100, 2011.
Levelt, P. F., Van den Oord, G. H. J., Dobber, M. R., Malkki, A., Visser, H., de Vries, J., Stammes, P., Lundell, J. O. V., and Saari, H.: The Ozone Monitoring Instrument, IEEE T. Geosci. Remote, 44, 1093-1101, 2006.

Li, K., Jacob, D. J., Liao, H., Shen, L., Zhang, Q., and Bates, K. H.: Anthropogenic drivers of 2013-2017 trends in summer surface ozone in China, P. Natl. Acad. Sci. USA, 116, 422-427, 2019.

Liu, X., Bhartia, P. K., Chance, K., Spurr, R. J. D., and Kurosu, T. P.: Ozone profile retrievals from the Ozone Monitoring Instrument, Atmos. Chem. Phys., 10, 2521-2537, https://doi.org/10.5194/acp-10-2521-2010, 2010.

Lu, X., Hong, J., Zhang, L., Cooper, O. R.,Schultz, M. G., Xu, X., Wang, T., Gao, M., Zhao, Y., and Zhang, Y.: Severe surface ozone pollution in China: a global perspective, Environ. Sci. Technol. Lett., 5, 487-494, 2018.

Ma, Z., Xu, J., Quan, W., Zhang, Z., Lin, W., and Xu, X.: Significant increase of surface ozone at a rural site, north of eastern China, Atmos. Chem. Phys., 16, 3969-3977, https://doi.org/10.5194/acp-16-3969-2016, 2016.

McPeters, R. D., Labow, G. J., and Logan, J. A.: Ozone climatological profiles for satellite retrieval algorithms, J. Geophys. Res., 112, D05308, https://doi.org/10.1029/2005JD006823, 2007.

Pendergrass, D. C., Shen, L., Jacob, D. J., and Mickley, L. J.: Predicting theimpact of climate change on severewintertime particulate pollution eventsin Beijing using extreme value theory, Geophys. Res. Lett., 46, 1824-1830, https://doi.org/10.1029/2018GL080102, 2019.

Rieder, H. E., Fiore, A. M., Polvani, L. M., Lamarque, J. F., and Fang, Y.: Changes in the frequency and return level of high ozone pollution events over the eastern United States following emission controls, Environ. Res. Lett., 8, 014012, https://doi.org/10.1088/1748-326/8/1/014012, 2013.

Schultz, M.G., Schröder, S., Lyapina, O., Cooper, O., Galbally, I., Petropavlovskikh, I., von Schneidemesser, E., Tanimoto, H., Elshorbany, Y., Naja, M., Seguel, R., Dauert, U., Eckhardt, P., Feigenspahn, S., Fiebig, M., Hjellbrekke, A.-G., Hong, Y.-D., Christian Kjeld, P., Koide, H., Lear, G., Tarasick, D., Ueno, M., Wallasch, M., Baumgardner, D., Chuang, M.-T., Gillett, R., Lee, M., Molloy, S., Moolla, R., Wang, T., Sharps, K., Adame, J.A., Ancellet, G., Apadula, F., Artaxo, P., Barlasina, M., Bogucka, M., Bonasoni, P., Chang, L., Colomb, A., Cuevas, E., Cupeiro, M., Degorska, A., Ding, A., Fröhlich, M., Frolova, M., Gadhavi, H., Gheusi, F., Gilge, S., Gonzalez, M.Y., Gros, V., Hamad, S.H., Helmig, D., Henriques, D., Hermansen, O., Holla, R., Huber, J., Im, U., Jaffe, D. A., Komala, N., Kubistin, D., Lam, K.-S., Laurila, T., Lee, H., Levy, I., Mazzoleni, C., Mazzoleni, L., McClure-Begley, A., Mohamad, M., Murovic, M., NavarroComas, M., Nicodim, F., Parrish, D., Read, K. A., Reid, N., Ries, L., Saxena, P., Schwab, J. J., Scorgie, Y., Senik, I., Simmonds, P., Sinha, V., Skorokhod, A., Spain, G., Spangl, W., Spoor, R., Springston, S. R., Steer, K., Steinbacher, M., Suharguniyawan, E., Torre, P., Trickl, T., Weili, L., Weller, R., Xu, X., Xue, L., and Zhiqiang, M.: Tropospheric Ozone Assessment Report: Database and Metrics Data of Global Surface Ozone Observations, Elem. Sci. Anth., 5, 58, https://doi.org/10.1525/elementa.244, 2017

Shen, L., Mickley, L. J., and Gilleland, E.: Impact of increasing heat waveson U.S. ozone episodes in the 2050s: Results from a multimodel analysisusing extreme value theory, Geophys. Res. 
Lett.,43，4017-4025, https://doi.org/10.1002/2016GL068432, 2016

Shen, L., Mickley, L. J., Leibensperger, E. M., and Li, M.: Strong dependenceof U.S. summertime air quality on thedecadal variability of Atlantic sea surface temperatures, Geophys. Res. Lett., 44, 12527-12535, https://doi.org/10.1002/2017GL075905, 2017.

Shim, C., Li, Q., Luo, M., Kulawik, S., Worden, H., Worden, J., Eldering, A., Diskin, G., Sachse, G., Weinheimer, A., Knapp, D., Montzca, D., and Campos, T.: Satellite observations of Mexico City pollution outflow from the Tropospheric Emissions Spectrometer (TES), Atmos. Environ., 43, 1540-1547, 2009.

Sun, L., Xue, L., Wang, T., Gao, J., Ding, A., Cooper, O. R., Lin, M., Xu, P., Wang, Z., Wang, X., Wen, L., Zhu, Y., Chen, T., Yang, L., Wang, Y., Chen, J., and Wang, W.: Significant increase of summertime ozone at Mount Tai in Central Eastern China, Atmos. Chem. Phys., 16, 10637-10650, https://doi.org/10.5194/acp-1610637-2016, 2016.

Theys, N., De Smedt, I., Yu, H., Danckaert, T., van Gent, J., Hörmann, C., Wagner, T., Hedelt, P., Bauer, H., Romahn, F., Pedergnana, M., Loyola, D., and Van Roozendael, M.: Sulfur dioxide retrievals from TROPOMI onboard Sentinel-5 Precursor: algorithm theoretical basis, Atmos. Meas. Tech., 10, 119-153, https://doi.org/10.5194/amt-10-119-2017, 2017.

Vos P.: Pearson's correlation between three variables; using students' basic knowledge of geometry for an exercise in mathematical statistics, Int. J. Sci. Math. Educ., 40, 533-554, 2009.

Wang, T., Wei, X. L., Ding, A. J., Poon, C. N., Lam, K. S., Li, Y. S., Chan, L. Y., and Anson, M.: Increasing surface ozone concentrations in the background atmosphere of Southern China, 1994-2007, Atmos. Chem. Phys., 9, 6217-6227, https://doi.org/10.5194/acp-9-6217-2009, 2009.

Wang, T., Xue, L. K., Brimblecombe, P., Lam, Y. F., Li, L., and Zhang, L.: Ozone pollution in China: A review of concentrations, meteorological influences, chemical precursors, and effects, Sci. Total Environ., 575, 1582-1596, 2017.

Zhang, L., Jacob, D. J., Liu, X., Logan, J. A., Chance, K., Eldering, A., and Bojkov, B. R.: Intercomparison methods for satellite measurements of atmospheric composition: application to tropospheric ozone from TES and OMI, Atmos. Chem. Phys., 10, 4725-4739, https://doi.org/10.5194/acp-10-4725-2010, 2010.

Zheng, B., Tong, D., Li, M., Liu, F., Hong, C., Geng, G., Li, H., Li, X., Peng, L., Qi, J., Yan, L., Zhang, Y., Zhao, H., Zheng, Y., He, K., and Zhang, Q.: Trends in China's anthropogenic emissions since 2010 as the consequence of clean air actions, Atmos. Chem. Phys., 18, 14095-14111, https://doi.org/10.5194/acp-18-140952018, 2018.
Ziemke, J. R., Chandra, S., and Bhartia, P. K.: Two new methods for deriving tropospheric column ozone from TOMS measurements: The assimilated UARS MLS/HALOE and convective-cloud differential techniques, J. Geophys. Res., 103, 22115-22127, 1998.

Ziemke, J. R., Chandra, S., Labow, G. J., Bhartia, P. K., Froidevaux, L., and Witte, J. C.: A global climatology of tropospheric and stratospheric ozone derived from Aura OMI and MLS measurements, Atmos. Chem. Phys., 11, 9237-9251, https://doi.org/10.5194/acp-11-9237-2011, 2011.

Ziemke, J. R., Oman, L. D., Strode, S. A., Douglass, A. R., Olsen, M. A., McPeters, R. D., Bhartia, P. K., Froidevaux, L., Labow, G. J., Witte, J. C., Thompson, A. M., Haffner, D. P., Kramarova, N. A., Frith, S. M., Huang, L.-K., Jaross, G. R., Seftor, C. J., Deland, M. T., and Taylor, S. L.: Trends in global tropospheric ozone inferred from a composite record of TOMS/OMI/MLS/OMPS satellite measurements and the MERRA-2 GMI simulation, Atmos. Chem. Phys., 19, 3257-3269, https://doi.org/10.5194/acp19-3257-2019, 2019.

Zoogman, P., Liu, X., Suleiman, R. M., Pennington, W. F., Flittner, D. E., Al-Saadi, J. A., Hilton, B. B., Nicks, D. K., Newchurch, M. J., Carr, J. L., Janz, S. J., Andraschko, M. R., Arola, A., Baker, B. D., Canova, B. P., Chan Miller, C., Cohen, R. C., Davis, J. E., Dussault, M. E., Edwards, D. P., Fishman, J., Ghulam, A., González Abad, G., Grutter, M., Herman, J. R., Houck, J., Jacob, D. J., Joiner, J., Kerridge, B. J., Kim, J., Krotkov, N. A., Lamsal, L., Li, C., Lindfors, A., Martin, R. V., McElroy, C. T., McLinden, C., Natraj, V., Neil, D. O., Nowlan, C. R., OSullivan, E. J., Palmer, P. I., Pierce, R. B., Pippin, M. R., Saiz-Lopez, A., Spurr, R. J. D., Szykman, J. J., Torres, O., Veefkind, J. P., Veihelmann, B., Wang, H., Wang, J., and Chance, K.: Tropospheric emissions: Monitoring of pollution (TEMPO), J. Quant. Spectrosc. Ra., 186, 17-39, https://doi.org/10.1016/j.jqsrt.2016.05.008, 2017.

Zoogman, P., Jacob, D. J., Chance, K., Zhang, L., Sager, P. L., Fiore, A. M., Eldering, A., Liu, X., Natraj, V., and Kulawik, S. S.: Ozone air quality measurement requirements for a geostationary satellite mission, Atmos. Environ., 45, 7143-7150, 2011. 